\title{
Research on Comprehensive Development of "Five Modernizations " in Xinjiang
}

\author{
Liu Jing ${ }^{1, a}$, Chen Tingwei ${ }^{2, b, *}$ \\ ${ }^{1} \mathrm{Ph}$.D. candidate of Faculty of Economics of Shandong University, Associate professor of Faculty of \\ International Economics and Trade, Shandong University of Finance and Economics, 250014, \\ Jinan, Shandong, China \\ ${ }^{2}$ Postgraduate of Faculty of International Economics and Trade of Shandong University of Finance \\ and Economics, 250014, Jinan, Shandong, China \\ a searuo@126.com, b729152571@qq.com
}

Keywords: agricultural modernization, greening, synergistic development

\begin{abstract}
As China's economy enters the new normal era, Xinjiang is now more focusing on the coordinated development of industrialization, urbanization, and modernization in agriculture, information and infrastructure. The paper starts from analyzing the development in the "five modernizations", and figures out the theoretical model of "five modernizations". By setting up an index system of the "five modernizations", the authors try to estimate the level and synergy degree of Xinjiang's "five modernizations" based upon Xinjiang's "five modernizations" synergy aspects. The empirical results show that, the value of the "five modernizations" is constantly improving. The level of Xinjiang's "five modernizations" is relatively low. Since the coupling and coordination level is in the primary stage in 2014, the level in Xinjiang has been continuously improving.
\end{abstract}

\section{Background of Study}

\subsection{Introduction}

In the past 40 years China's economy as well as people's living standards has been developing rapidly. In the process of our five modernizations, we need to follow a path of sound development that emphasizes both quality and quantity. In particular, the coordinated development of the "five modernizations" system is related to the overall situation of the modernization drive. The northwest region is vital for China's western region development, and Xinjiang is an extremely important link, it also plays an important role in the development of "One Belt and One Road". As the development of Xinjiang is relatively backward, the research on the simultaneous development of "five modernizations" is in response to the national strategy and out of practical needs. At present, Xinjiang is still in the primary stage of industrialization, and its development is not coordinated in terms of industrial structure. In recent five years, the urbanization rate of Xinjiang has been maintained at around $40 \%$, with a moderate development speed. However, there are problems such as unreasonable industrial structure and weak urban economy. Xinjiang is a big agricultural province, but the degree of agricultural modernization is still in the embryonic stage.

\subsection{Mechanism of coordinated development of "five modernizations"}

The coordinated development of the "five modernizations" is a powerful driving force for national economic and social development under the new normal [4,5]. The deepening degree of industrialization is conducive to the rapid development of advanced production factors and technologies and the improvement of agricultural production efficiency. New urbanization is an important development platform for the five modernizations. Urbanization provides elements and product markets for industrial development. The new urbanization into information to provide high intelligence level talents [6]. Agricultural modernization is the basic resource base for "five modernizations". Agricultural modernization and industrialization promote each other, showing a positive correlation; Informationization is the intelligent control center of the coordinated development of "five modernizations". With the improvement of information technology, the 
automation level of related manufacturing and infrastructure industries has been improved. Greening is the banner of civilization for the coordinated development of "five modernizations". First, "clear water and green mountains" mean "mountains of gold and silver". Greening is an important link in the construction of ecological civilization $[7,8]$. Second, we should reduce energy consumption and pollution in industrialization, make scientific alnd rational use of resources, and build a beautiful China with blue sky, green mountains and green water as soon as possible.

\section{Method}

\subsection{Weight determination and evaluation calculation}

There are many methods to assign weight to indicators, such as expert scoring method, factor analysis method, entropy method and so on. Entropy method is adopted in this paper. Entropy method is to determine the weight by the information provided by the index. Information entropy is inversely proportional to the information provided by this index. Therefore, the smaller the information entropy is, the more information is provided, and the larger the corresponding weight is, and vice versa. The calculation process is as follows [9].

Proportion value of the $\mathrm{J}$ in the I year $P_{i j}: P_{i j}=Y_{i j} / \sum_{i=1}^{n} Y_{i j}$

Information entropy of index $\mathrm{J} G_{j}: G_{j}=-K \sum_{i=1}^{n} P_{i j} \ln P_{i j}, K=1 / \ln (n)$

Difference degree of index $\mathrm{J} H_{j}: H_{j}=1-G_{j}$ (3)

Evaluation value of index $\mathrm{J}$ in year $L_{i j}: l_{1} j=w_{j} \times P_{i j}$

Synthesis of systems in the first year $L_{i}: L_{i}=\sum_{j=1}^{m} L_{i j}$

Where is the weight of each index, and is the comprehensive evaluation value of the $J$ index in the first year. $W_{j}$ is the weight of each index, $\operatorname{and} L_{i j}$ is the comprehensive evaluation value of the $j$ index in the I year.

\subsection{Coupling coordination model}

According to the system coupling model in physics, the degree of interaction between the coupling elements of the five systems reflects the degree of their mutual coordination, and is defined as the degree of coupling of the five systems. Its formula is:

$$
C=\left\{\frac{\left(s_{1} \times s_{2} \times s_{3} \times s_{4} \times s_{5}\right)}{\frac{\left(s_{1}+s_{2}+s_{3}+s_{4}+s_{5}\right)^{5}}{5}}\right\}^{\frac{1}{5}}
$$

$s_{i}$ respectively represents the development level index of the five subsystems of new industrialization, new urbanization, agricultural modernization, informatization and greening. $C$ belongs to $(0,1)$, and the larger $C$ value indicates the greater degree of interaction between the systems [9]. The degree of coupling $C$ sometimes does not reflect the actual level of development of each. The coupling coordination degree model can not only reflect the degree of coupling coordination between each transformation, but also truly reflect the relative level of development of each transformation. Its formula is as follows:

$$
\begin{gathered}
D=\sqrt{C \times T} \\
T=\lambda_{1} S_{1}+\lambda_{2} S_{2}+\lambda_{3} S_{3}+\lambda_{4} S_{4}+\lambda_{5} S_{5}
\end{gathered}
$$

Where $D$ is the coupling coordination degree, $\mathrm{T}$ is the comprehensive development level index of "five modernization", and is the undetermined coefficient [10]. According to the internal mechanism of coupling and coordination development of "five modernizations" as 
explained above, this paper summarizes the $D$ value between $(0,1)$. When the $\mathrm{D}$ value approaches 1 , the coordination degree of "five modernizations" is the highest, and when it approaches 0 , the coordination degree is the lowest.

\section{Results and Discussion}

\subsection{Measurement results of index weight of coordinated development of "five modernizations" in Xinjiang}

According to formula (1) - (7), the weights of indicators in the "five modernizations" system in Xinjiang from 2002 to 2014 were calculated. Such as table 1.

Table 1: Comprehensive evaluation index weight of coordinated development of "five modernizations" in Xinjiang

\begin{tabular}{|c|c|c|c|}
\hline First level index & second level index & third level index & $\begin{array}{l}\text { Entropy } \\
\text { weight }\end{array}$ \\
\hline \multirow{13}{*}{$\begin{array}{l}\text { New } \\
\text { industrialization } \\
\text { subsystem }\end{array}$} & \multirow{4}{*}{$\begin{array}{l}\text { Industrialization level and } \\
\text { structure }\end{array}$} & GDP per capita & 0.09 \\
\hline & & Industrial added value per capita & 0.114 \\
\hline & & Rate of industrialization & 0.01 \\
\hline & & The proportion of non-farm employment & 0.004 \\
\hline & \multirow{3}{*}{$\begin{array}{l}\text { Technological content and } \\
\text { human potential }\end{array}$} & $\begin{array}{l}\text { The number of patent applications approved } \\
\text { for ten thousand people }\end{array}$ & 0.279 \\
\hline & & $\begin{array}{c}\text { The proportion of R\&D expenditure in } \\
\text { Xinjiang's GDP }\end{array}$ & 0.074 \\
\hline & & $\begin{array}{c}\text { Every } 100,000 \text { people with a college degree } \\
\text { or above }\end{array}$ & 0.033 \\
\hline & \multirow[b]{2}{*}{ Industrial economic benefit } & Profit margin of industrial cost & 0 \\
\hline & & $\begin{array}{c}\text { Full labor productivity of industrial } \\
\text { enterprises above scale }\end{array}$ & 0.175 \\
\hline & \multirow[t]{2}{*}{ Resource consumption } & $\begin{array}{c}\text { Ten thousand yuan of industrial added value } \\
\text { energy consumption }\end{array}$ & 0.003 \\
\hline & & Ten thousand-yuan GDP water consumption & 0.082 \\
\hline & \multirow{2}{*}{$\begin{array}{l}\text { The environmental } \\
\text { protection }\end{array}$} & $\begin{array}{l}\text { The total investment in environmental } \\
\text { pollution control accounted for the } \\
\text { proportion of Xinjiang's GDP }\end{array}$ & 0.116 \\
\hline & & $\begin{array}{l}\text { Comprehensive industrial "three wastes" } \\
\text { emission index }\end{array}$ & 0.021 \\
\hline \multirow{11}{*}{$\begin{array}{l}\text { Subsystem of } \\
\text { new urbanization }\end{array}$} & \multirow{2}{*}{ Economic urbanization } & Proportion of non-agricultural industries & 0.001 \\
\hline & & GDP per unit built-up area & 0.052 \\
\hline & \multirow[t]{2}{*}{ Social urbanization } & $\begin{array}{l}\text { Participate worker basic endowment } \\
\text { insurance coverage rate }\end{array}$ & 0.51 \\
\hline & & Number of hospital beds per 10,000 people & 0.056 \\
\hline & \multirow[t]{2}{*}{ Spatial urbanization } & $\begin{array}{l}\text { The number of urban populations absorbed } \\
\text { by unit built-up area }\end{array}$ & 0.01 \\
\hline & & Per capita living space of urban residents & 0.008 \\
\hline & \multirow[t]{2}{*}{ Urbanization of life } & $\begin{array}{l}\text { Harmless disposal rate of municipal solid } \\
\text { waste }\end{array}$ & 0.32 \\
\hline & & Green coverage rate of built-up area & 0.01 \\
\hline & \multirow{3}{*}{ Urban-rural integration } & Population urbanization rate & 0.016 \\
\hline & & $\begin{array}{l}\text { The ratio of urban per capita disposable } \\
\text { income to rural per capita income }\end{array}$ & 0.002 \\
\hline & & Urban and rural Engel coefficient ratio & 0.015 \\
\hline \multirow{5}{*}{$\begin{array}{l}\text { Agricultural } \\
\text { modernization } \\
\text { subsystem }\end{array}$} & \multirow{3}{*}{$\begin{array}{l}\text { Agricultural production input } \\
\text { level }\end{array}$} & Mechanical power per unit cultivated land & 0.057 \\
\hline & & Water-saving irrigation area ratio & 0.025 \\
\hline & & $\begin{array}{l}\text { Rural per capita fixed assets investment in } \\
\text { agriculture, forestry, animal husbandry and } \\
\text { fishery }\end{array}$ & 0.079 \\
\hline & \multirow{2}{*}{$\begin{array}{l}\text { Agricultural science and } \\
\text { technology level }\end{array}$} & $\begin{array}{c}\text { Proportion of agricultural and agricultural } \\
\text { technicians }\end{array}$ & 0.019 \\
\hline & & $\begin{array}{l}\text { The number of teachers per ten thousand } \\
\text { people in rural areas }\end{array}$ & 0 \\
\hline
\end{tabular}




\begin{tabular}{|c|c|c|c|}
\hline & Agricultural production level & $\begin{array}{l}\text { Agricultural productivity } \\
\text { Land yield }\end{array}$ & $\begin{array}{l}0.024 \\
0.035\end{array}$ \\
\hline & Level of social development & $\begin{array}{l}\text { Commodity rate of agricultural products } \\
\text { Processing rate of agricultural products }\end{array}$ & $\begin{array}{l}0.026 \\
0.014\end{array}$ \\
\hline & Living standard of farmers & $\begin{array}{l}\text { The per capita net income of farmers } \\
\text { Engel coefficient }\end{array}$ & $\begin{array}{l}0.243 \\
0.013 \\
\end{array}$ \\
\hline & $\begin{array}{c}\text { Level of sustainable } \\
\text { development }\end{array}$ & $\begin{array}{l}\text { The proportion of soil erosion control area } \\
\text { Forest pest control rate }\end{array}$ & $\begin{array}{l}0.391 \\
0.074 \\
\end{array}$ \\
\hline \multirow{3}{*}{$\begin{array}{l}\text { Information } \\
\text { subsystem }\end{array}$} & $\begin{array}{l}\text { Information resources and } \\
\text { equipment }\end{array}$ & $\begin{array}{c}\text { A hundred people have a collection of } \\
\text { books in the public library } \\
\text { Number of mobile phones per } 100 \text { persons } \\
\text { The proportion of Internet users } \\
\text { Comprehensive population coverage of TV } \\
\text { programs } \\
\end{array}$ & $\begin{array}{c}0.021 \\
0.228 \\
0.359 \\
0\end{array}$ \\
\hline & $\begin{array}{l}\text { Information technology } \\
\text { application and industry }\end{array}$ & $\begin{array}{c}\text { The electronic and communication } \\
\text { equipment manufacturing industry } \\
\text { accounted for a percentage of GDP } \\
\text { Information transmission, computer services } \\
\text { and software accounted for a percentage of } \\
\text { GDP }\end{array}$ & 0.266 \\
\hline & Information on the subject & $\begin{array}{c}\text { Ten thousand R\&D full-time personnel } \\
\text { The proportion of employees employed in } \\
\text { information transmission, computer service } \\
\text { and software industry }\end{array}$ & 0.099 \\
\hline \multirow[t]{2}{*}{ Green subsystem } & $\begin{array}{l}\text { Water supply and drainage } \\
\text { system }\end{array}$ & $\begin{array}{c}\text { Urban sewage treatment rate } \\
\text { Average length of drainage pipe per } 10,000 \\
\text { people }\end{array}$ & $\begin{array}{l}0.005 \\
0.136\end{array}$ \\
\hline & Garden sanitation system & Health technicians per 10,000 people & 0.014 \\
\hline
\end{tabular}

3.2 Measurement results of coupling coordination degree of "five modernizations" in Xinjiang

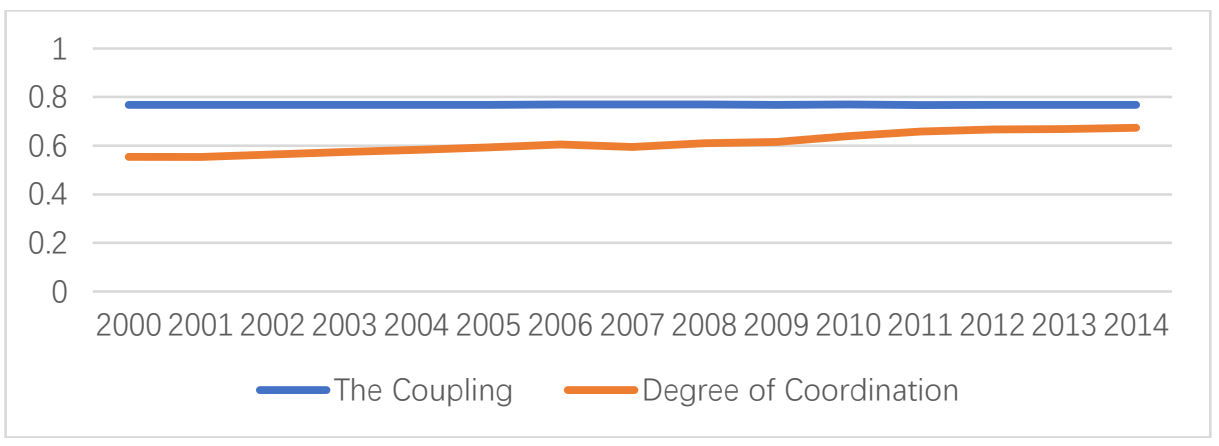

Figure 1: The coupling co scheduling of "five modernizations" in Xinjiang from 2000 to 2014

From 2000 to 2006, the D value of coupling coordination degree of " five modernizations " was $(0.5001,0.6000)$, indicating that Xinjiang's " five modernizations " was in a stage of barely coordinated. From 2007 to 2014, D value was $(0.6001,0.7000)$, indicating that the coordinated development of Xinjiang's "five modernizations" was constantly improving and reached the stage of primary coordination. With the continuous progress of "five modernizations" and strong support from Xinjiang government, the coupling coordination degree of "five modernizations" in Xinjiang increased by 0.119568 from 0.554202 in 2000 to 0.67377 in 2014 . 


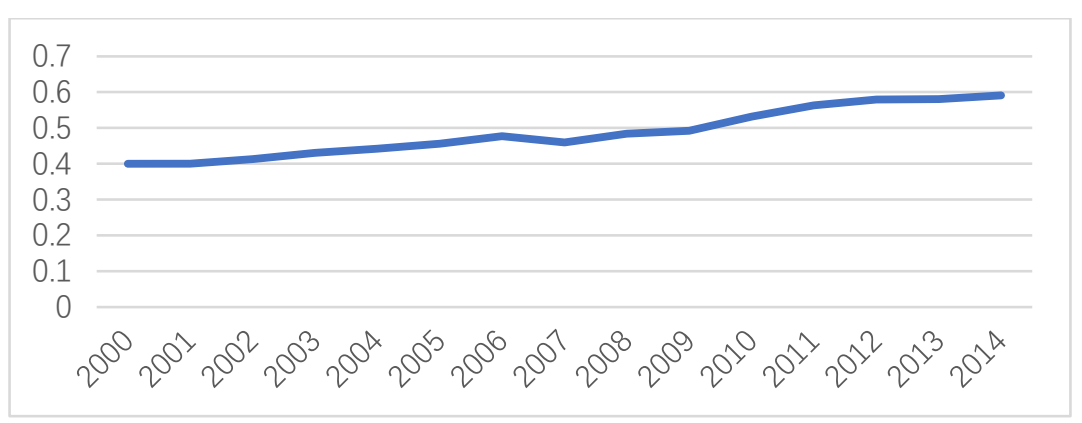

Figure 2: Xinjiang's comprehensive development level index of "five modernizations" from 2000 to 2014 (T)

As can be seen from Figure 2, from 2000 to 2014, the comprehensive development level of Xinjiang's "five modernizations" increased by $47.7 \%$ compared with that of 2000 , except for a slight decline in 2007.

\subsection{Discussion of the results}

Table 2: Coordinated development of "five modernizations" in Xinjiang from 2000 to 2014

\begin{tabular}{cccccc}
\hline & $\begin{array}{c}\text { New } \\
\text { industrialization } \\
\text { index S1 }\end{array}$ & $\begin{array}{c}\text { New urbanization } \\
\text { index S2 }\end{array}$ & $\begin{array}{c}\text { Agricultural } \\
\text { modernization index } \\
\text { S3 }\end{array}$ & $\begin{array}{c}\text { Informationization } \\
\text { index S4 }\end{array}$ & Green index S5 \\
\hline 2000 & 0.3401473 & 0.60010948 & 0.40536521 & 0.277339 & 0.339187 \\
2001 & 0.33677898 & 0.60035313 & 0.41277683 & 0.279577 & 0.336755 \\
2002 & 0.36325279 & 0.60077082 & 0.42315522 & 0.281389 & 0.359998 \\
2003 & 0.37685846 & 0.61332564 & 0.44828964 & 0.299443 & 0.376679 \\
2004 & 0.38025737 & 0.61125446 & 0.48969592 & 0.31773 & 0.379981 \\
2005 & 0.39037295 & 0.63514264 & 0.51563008 & 0.321605 & 0.390171 \\
2006 & 0.40112192 & 0.610153 & 0.53190613 & 0.328977 & 0.496971 \\
2007 & 0.40219412 & 0.62696435 & 0.49939322 & 0.335764 & 0.401938 \\
2008 & 0.42171327 & 0.66399371 & 0.51170037 & 0.367463 & 0.420521 \\
2009 & 0.41097806 & 0.70090277 & 0.52367452 & 0.390958 & 0.398503 \\
2010 & 0.46377939 & 0.73256925 & 0.54722784 & 0.425494 & 0.452709 \\
2011 & 0.51219409 & 0.84117388 & 0.57330755 & 0.419914 & 0.409196 \\
2012 & 0.50085129 & 0.84067688 & 0.58646619 & 0.420165 & 0.500343 \\
2013 & 0.5018697 & 0.84035536 & 0.60240613 & 0.410564 & 0.50123 \\
2014 & 0.51337533 & 0.84059867 & 0.64357677 & 0.396835 & 0.513463 \\
\hline Compren
\end{tabular}

Comprehensive evaluation value analysis: It can be seen from table 5, from 2000 to 2014, the overall development level of Xinjiang during the "five modernizations" period increased substantially. The level of new industrialization will rise by 1.5 times, that of new urbanization by 1.4 times, that of agricultural modernization by 1.6 times, that of informatization by 1.44 times and that of greening by 1.5 times. This shows that during the past 15 years, Xinjiang's modernization process has developed rapidly and all aspects of the "five modernizations" have achieved results. Except for slight fluctuations in the level of green development in some years, new urbanization, new industrialization, agricultural modernization and information technology are on the whole on the rise. Information level started to low because at that time, the province's overall informatization level is not high and that computer technology related industries as a share of GDP is relatively low, while the other "four modernizations" although at that time also are in the early stage of development, but the accumulation of advantages or has ever better than becoming an information based society development.

\section{Conclusion}

Based on the theory of synergistic development of the five modernizations, I come to the following conclusions

1. The coupling and coordination degree of Xinjiang's "five modernizations" is very low. From 2000 to 2006, the D value of coupling coordination degree of Xinjiang's "five modernizations" belongs to $(0.5001,0.6000)$, indicating that this stage is in the stage of grudging coordination. From 
2007 to 2014, D value belongs to $(0.6001,0.7000)$, which is in the primary coordination stage. However, the coupling coordination degree of Xinjiang's "five modernizations" keeps improving.

2. From 2000 to 2014, the level of new urbanization has been ahead of other four modernizations, with the new industrialization and agricultural modernization at a general level, while the level of information and green development is lower, which has lagged behind other three modernizations. Information has not integrated with other four modernizations, and cannot play a huge role in promoting the development of the engine. The level of green development is very low, and the growth rate is the slowest. The gap between green development and new urbanization, new industrialization and agricultural modernization is gradually increasing, and it has not played its role as the basis for the development of other four modernizations. The degree of interaction and dependence between Xinjiang's "five modernizations" is relatively low. Until 2014, the level of coupling coordination was still in the primary coordination stage.

\section{References}

[1] Aimer, N., 2016. 'The Effects of Oil Price Volatility on the Economic Sectors of Libya'. International Journal of Business and Social Research, vol.6, no. 12, pp. 13-24.

[2] Zhu hui. Measurement of coordinated development of Xinjiang production and construction corps. Rural economy and technology, vol. 25, 2014

[3] Zhou Zhenhua. New industrialization road: the interaction and fusion of industrialization and informatization. Shanghai economic research, 2002(12):5 7

[4] Feng xian et al. The connotation of industrialization, informationization, urbanization and agricultural modernization in China and the realistic choice and action mechanism of synchronous development. Agricultural modernization research [J], 2013 (5) : 269-273.

[5] Li Lichun. Evaluation of benefit level of China's agricultural modernization from the perspective of postmodern agriculture. Agricultural economics, 2013(12):7-144

[6] Xu Changsheng. The relationship between informatization and industrialization [J]. Economic research reference, 2001(31):35-36.

[7] Gao Zhigang, Gong Wei. Comparative study on the development level of regional new-type industrialization -- a case study of Xinjiang prefectural region [J]. Development research, 2012(06):12-15.

[8] Chen Zhongchang, Jiang Jianhui, Gong Rui. Study on evaluation model of urban greening [J]. Economics and management research, 2010(06):70-76.

[9] Feng Xian and Cui kai. The connotation of industrialization, informatization, urbanization and agricultural modernization in China and the practical selection and action mechanism of synchronous development [J]. Agricultural modernization research, 2013(03):269-273.

[10]Dong Meisheng and Yang Decai. Research on the interaction between industrialization, informatization, urbanization and agricultural modernization -- based on VAR model [J]. Agricultural technology and economy, 2014(04):14-24. 